\title{
GC-MS analysis, antibacterial, antioxidant study and brine shrimp lethality analysis of Trachyspermum ammi (L.) Sprague
}

\author{
Shova D.C. ${ }^{1}$, Binita Maharjan ${ }^{1}$, Timila Shrestha ${ }^{1}$, Samjhana Bharati ${ }^{2}$, Shree Dhar Gautam ${ }^{1}$, Ram Lal Shrestha ${ }^{1 *}$ \\ ${ }^{1}$ Department of Chemistry, Amrit Campus, Tribhuvan University, Kathmandu, Nepal \\ ${ }^{2}$ Department of Chemistry, Tri-Chandra Multiple Campus, Tribhuvan University, Kathmandu, Nepal \\ ${ }^{*}$ Email: swagatstha@hotmail.com
}

(Received: 22 April, 2020, Received in revised form: 12 August, 2020, Accepted: 17 August, 2020, Available online)

\section{Highlights}

- Fruit part of T. ammi was subjected to extraction of essential oil by hydrodistillation.

- GC-MS analysis showed the presence of 10 different compounds.

- Essential oil was active towards different bacterial species during antibacterial studies.

- Antioxidant analysis confirmed the $\mathrm{IC}_{50}$ value of the oil against $\mathrm{DPPH}$ as $0.94 \mathrm{mg} / \mathrm{mL}$.

- $\mathrm{LC}_{50}$ was calculated to be $26.2 \mu \mathrm{g} / \mathrm{mL}$ through brine shrimp lethality analysis.

\section{Abstract}

Fruit part of Trachyspermum ammi (L.) Sprague was subjected to extraction of essential oil by hydrodistillation in Clevenger apparatus. So collected essential oil was analyzed by GC-MS for its composition and exhibited the presence of 10 different compounds. The most abundant were $\gamma$-terpinene (53.81\%) and thymol (29.40\%). Antibacterial activity was performed against six bacterial species and Staphylococcus aureus, Enterobacter cloaceae and Bacillus subtilis were the most susceptible to the essential oil showing zone of inhibition (ZOI) $1.4,1.5$ and $1.4 \mathrm{~cm}$ respectively. The $I_{50}$ value of the oil against DPPH was found to be $0.94 \mathrm{mg} / \mathrm{mL}$. The $L C_{50}$ value of essential oil of T. ammi against brine shrimp was found $26.2 \mu \mathrm{g} / \mathrm{mL}$.

Keywords: Trachyspermum ammi, Essential oil, GC-MS, Bio-activity

\section{Introduction}

Trachyspermum ammi, which is commonly known as Bishop's weed and locally known as Jwano, is a herbaceous plant which belongs to the family Apiaceae and has high medicinal value. This plant has an erect stem which may grow up to $90 \mathrm{~cm}$ tall. This plant is widely distributed in various regions such as Iran, Pakistan, Afghanistan, India and Nepal as well as in Europe. But this plant is indigenous to Egypt (Shojaaddini et al., 2008). It is grown in arid and semi-arid regions where soil contains a high level of salts. It is generally a branched annual herb which produces white bisexual flowers. Fruits are about $2 \mathrm{~mm}$ long and $1.7 \mathrm{~mm}$ wide. Fruits of T. ammi accumulate up to $5 \%$ essential oil in its compartments. Presence of essential oil is responsible for its odour and taste. Due to its characteristic pungent smell, it is widely used in Nepalese kitchen as a spice, flavoring agent, preservative and for the preparation of various medicines (Bairwa et al., 2012).

It has been widely used in traditional medicine practice for a variety of medicinal and pharmacological aspects. The fruits of T. ammi possess antispasmodic, stimulant and carminative properties and is conventionally used as a curative agent for abdominal pains, diarrhea, piles, abdominal tumours, atonic dyspepsia, flatulence, and bronchial problems, lack of appetite, galactagogue, asthma and amenorrhoea (Ranjan et al., 2012).

${ }^{*}$ Corresponding author 
T. ammi oil is extracted from fruits by steam distillation process. It is brownish liquid with characteristic odour and bitter taste. The fruits of $T$. ammi mainly constitute the volatile oil which contains more amounts of thymol, $\gamma$-terpinene and p-cymene (Moazeni et al., 2012). The T. ammi oil components thymol and caracole have attributes for antibacterial and antifungal action against a wide range of microbes (Vazirzadeh et al., 2013). Thymol can be used in disinfection of mild to moderate dermal injuries as it cures the injuries fast. It is also used in mouthwash, sterilizations and as a hair rinse for curing of dandruff problems (Chung et al., 2007). It also contains a small amount of other phytochemicals such as pinene, cymene, limonene and terpinene. Apart from these, T. ammi fruits are also a rich source of fiber, minerals, vitamins and anti-oxidants (Chahal et al., 2017). It is also reported that the essential oil can exhibit insecticidal activity. It was also evaluated for exhibiting anti-inflammatory effect. It was also revealed that the dietary T. ammi extracts would reduce the toxicity resulted from hepatic free radical stress. It was also reported that it showed teratogenicity in rat fetuses. Therefore, it may be harmful to intake during pregnancy (Zarshenas et al., 2013).

We have implemented the hydrodistillation technique for the extraction of essential oil from T. ammi collected from Dang, Nepal and have performed different biological tests for knowing the potency of the essential oil as antioxidant, antibacterial, cytotoxic etc. For knowing the chemical composition of the oil, GC-MS analysis was also done. Though some aspects of researches have been performed of the T. ammi cultivated in different geographical areas, the objective of the research is to find out the composition and activities of essential oil of T. ammi cultivated in a specific area, Dang, Nepal.

\section{Experimental}

\section{Collection of plant materials}

The fresh T. ammi fruits were collected from Dang, Nepal. The specimen was identified by Department of Botany, Amrit Science Campus, Lainchaur, Kathmandu, Nepal.

\section{Extraction of essential oil}

Clevenger apparatus was used for extraction of essential oil via hydrodistillation method. From 950g of fruits of T. ammi, $7 \mathrm{~mL}$ of oil was obtained after boiling the fruits in distilled water for 3 hours in Clevenger apparatus). The essential oil was collected and stored in a sealed glass vials at low temperature $\left(0-4^{\circ} \mathrm{C}\right)$ prior to analysis (Khajeh et al., 2004).

\section{GC-MS analysis}

GC-MS analysis was performed in Department of Food Technology and Quality Control, Babarmahal, Kathmandu, Nepal, on a gas chromatography mass spectrometer GCMS-QP2010. The analysis was done under the conditions as mentioned: injection volume was maintained $1 \mu \mathrm{L}$ with split ratio 1:90; Helium gas was used as a carrier gas with a Rtx-5MS column of dimension $30 \mathrm{~m} \times 0.25 \mathrm{~mm} \times 0.25 \mu \mathrm{m}$, at 50,150 and $250^{\circ} \mathrm{C}$ temperature with a hold time of $0.0,2.0$ and 5.0 minutes. The identification was done amid comparison of MS with those reported in NIST 05 and FFNSCI.3 libraries. (Dhaiwal et al., 2017).

\section{Antibacterial activity}

Antibacterial activity of essential oil of T. ammi was performed by using agar well diffusion method in Muller Hilton Agar (MHA) based on the procedure given by Medini et al., 2014. In this method, for the estimation of antibacterial activity of the oil, the average diameter of zone of inhibition (ZOI) produced by essential oil on particular pathogenic bacteria were measured. All the strains of bacteria were cultured in Nutrient broth (NB) and incubated at $37^{\circ} \mathrm{C}$ for 18 hours. Each strain was diluted with sterile distilled water after incubation. The turbidity of dilution was compared with 0.5 McFarland standards (approximately $10^{8} \mathrm{CFU} / \mathrm{mL}$ ). To obtain $10^{6} \mathrm{CFU} / \mathrm{mL}$, the suspensions were then diluted (1:100) in Muller Hilton Broth (MHB). The prepared inoculums were incubated at $37^{\circ} \mathrm{C}$ for 30 minutes prior to use (Gandomi et al., 2014).

With the help of micropipette, essential oil of T. ammi $(30 \mu \mathrm{L})$ was loaded into the respective wells. At the same time, $50 \%$ DMSO (solvent) was tested for its activity as a control in the separate well. A positive control, neomycin $20 \mu \mathrm{g} / \mathrm{mL}$ was used. For letting the extracts to diffuse to the media, the plates were then left for half an hour with the lid closed. The plates were incubated overnight at $37^{\circ} \mathrm{C}$. The plates were observed for the zone of inhibition around well which is suggested by clean zone without growth, after proper incubation for 24 hours. The ZOI was measured with ruler and mean was recorded for the estimation of the potency of antibacterial substance (Opoku and Akoto, 2015). 


\section{Antioxidant assay (DPPH method)}

Antioxidant assay was performed against DPPH. At first, for preparing stock solution of concentration $1 \mathrm{mg} / \mathrm{mL}, 1 \mathrm{mg}$ of sample to be tested was dissolved in $1 \mathrm{~mL}$ methanol. Then $100 \mu \mathrm{L}$ of these solutions were added to $100 \mu \mathrm{L}$ of $0.1 \mathrm{mM}$ DPPH (prepared in methanol) and was left for 30 minutes in darkroom. After 30 minutes, their absorbance was taken at $517 \mathrm{~nm}$ against DPPH. DMSO was used for a blank test and as standard Quercetin was prepared. The essential oil, which did not show antioxidant property, was discarded. The sample with the yellow colour (more than $50 \%$ inhibition then control) was taken for further testing. These were expected to be the potent antioxidants (Singh et al., 2005).

Different concentrations of the extracts were prepared by two-fold dilution method to find the $\mathrm{IC}_{50}$ value against DPPH (Singh \& Ahmad, 2017).

By using the following formula, the percentage of radical scavenging activity was calculated:

Percentage scavenging $=\frac{A_{O}-A_{T}}{A_{T}} \times 100$

Where, $\mathrm{A}_{0}=$ Absorbance of DPPH

$\mathrm{A}_{\mathrm{T}}=$ Absorbance of the DPPH free radical solution containing the sample extract

The $50 \%$ inhibitory concentration value $\left(\mathrm{IC}_{50}\right)$ is specified as effective concentration of the sample required to scavenge $50 \%$ of the DPPH free radicals. The antioxidant capacity of plants is clearly associated with the activity of "free radical scavenging enzymes". The antioxidant potential is inversely proportional to the $\mathrm{IC}_{50}$ value, i.e., lower the $\mathrm{IC}_{50}$ value it indicates high antioxidant activity and vice versa (Chatterjee et al., 2013).

\section{Brine Shrimp lethality assay}

Brine shrimp lethality assay is a significant tool for the initial cytotoxicity assay of plant extract and others. This assay is based on the capability to kill a larvae (nauplii) cultured in laboratory. It is a simple, cost-effective as it involves a small amount of test material. The nauplii of brine shrimp (Artemia salina) were exposed to different concentrations of essential oil of T. ammi for 24 hours. The number of motile nauplii was calculated that represented the effectiveness of the oil.

$\mathrm{LC}_{50}$ values lower than $1000 \mu \mathrm{g} / \mathrm{mL}$ are considered bioactive in toxicity evaluation by Brine shrimp lethality assay of plant extracts and essential oil (Meyer et al., 1982).

\section{Results and Discussion}

From the hydrodistillation process in Clevenger Apparatus, a slight yellowish coloured oil, transparent in appearance, little peppery in smell and bitter in taste was obtained which was subjected to further analysis and activities.

\section{GC-MS analysis}

Gas chromatographic analysis resulted in the identification of a total of 10 different constituents. The essential oil was found to contain mostly $\gamma$-terpinene (53.81\%) and thymol (29.40\%) as presented in Table 1.

Table 1: Percentage composition of essential oils

\begin{tabular}{|l|l|c|c|c|c|}
\hline \multicolumn{1}{|c|}{ S.N. } & \multicolumn{1}{|c|}{ Name of the compounds } & $\begin{array}{c}\text { Retention time } \\
(\mathrm{min})\end{array}$ & $\begin{array}{c}\text { Molecular } \\
\text { formula }\end{array}$ & $\begin{array}{c}\text { Molecular } \\
\text { weight }\end{array}$ & Area (\%) \\
\hline 1. & $\alpha$-Thujene & 6.924 & $\mathrm{C}_{10} \mathrm{H}_{16}$ & 136 & 1.08 \\
\hline 2. & $\beta$-Pinene & 7.833 & $\mathrm{C}_{10} \mathrm{H}_{16}$ & 136 & 4.55 \\
\hline 3. & $\beta$-Myrcene & 8.035 & $\mathrm{C}_{10} \mathrm{H}_{16}$ & 136 & 1.55 \\
\hline 4. & $\alpha$-Terpinene & 8.506 & $\mathrm{C}_{10} \mathrm{H}_{16}$ & 136 & 1.55 \\
\hline 5. & $\gamma$-Terpinene & 9.242 & $\mathrm{C}_{10} \mathrm{H}_{16}$ & 136 & 53.81 \\
\hline
\end{tabular}




\begin{tabular}{|l|l|c|c|c|c|}
\hline 6. & cis-4-Thujanol & 9.886 & $\mathrm{C}_{10} \mathrm{H}_{18} \mathrm{O}$ & 154 & 2.09 \\
\hline 7. & 4-Terpineol & 11.142 & $\mathrm{C}_{10} \mathrm{H}_{18} \mathrm{O}$ & 154 & 1.37 \\
\hline 8. & Thymol & 12.765 & $\mathrm{C}_{10} \mathrm{H}_{14} \mathrm{O}$ & 150 & 29.40 \\
\hline 9. & 6-Ethyl-3,4-dimethylphenol & 12.892 & $\mathrm{C}_{14} \mathrm{H}_{14} \mathrm{O}$ & 150 & 0.81 \\
\hline 10. & Diethyl Phthalate & 16.678 & $\mathrm{C}_{12} \mathrm{H}_{14} \mathrm{O}_{4}$ & 222 & 3.78 \\
\hline
\end{tabular}

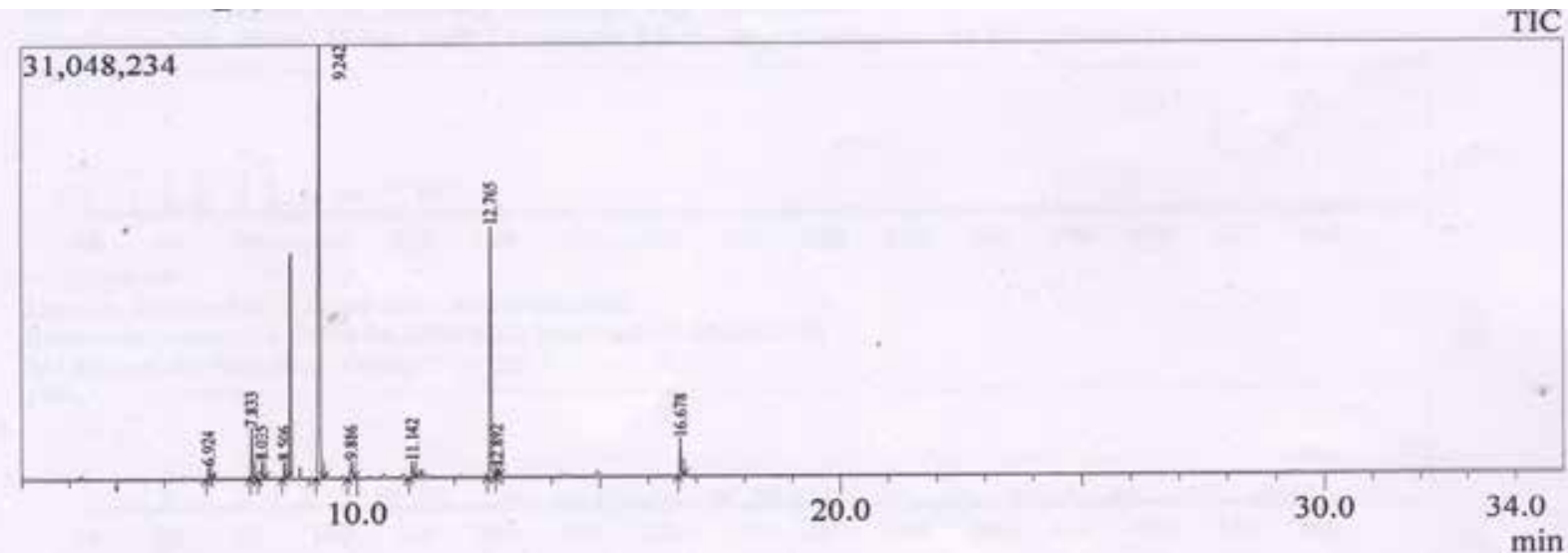

Fig 1: Chromatogram of GC-MS analysis of essential oil of Trachyspermumammi

\section{Antibacterial activity}

The zone of inhibition for six bacteria sample that were examined, is shown in the table. The ZOI of Enterobacter cloaceae was observed to be largest $(1.5 \mathrm{~cm})$ than other bacteria. And ZOI of Micrococcus luteus was observed to be least $(1 \mathrm{~cm})$ present in Table 2.

Table 2: Antibacterial activity in diameter (cm) of inhibition zone

\begin{tabular}{|l|c|}
\hline Bacteria tested & $\begin{array}{c}\text { Diameter of well }(\varphi)=0.6 \mathrm{~cm} \\
\text { Diameter of zone of inhibition }(\mathrm{cm})\end{array}$ \\
\hline Staphylococcus aureus KCTC 1916 & 1.4 \\
\hline Klebsiella pneumonia & 1.2 \\
\hline Enterobacter cloaceae KACC 13002 & 1.5 \\
\hline Bacillus subtilis KACC 17047 & 1.4 \\
\hline Micrococcus luteus KACC 13377 & 1.0 \\
\hline Pseudomonas aeruginosa KACC 10232 & 1.2 \\
\hline
\end{tabular}

The result shows that the essential oil of $T$. ammi is very effective for antibacterial activities. From the table we can see that itgives better result in Gram +ve bacteria than the Gram -ve bacteria among the examined species. The essential oil of T. ammi can be used in the development of different antibiotic medicines.

\section{Antioxidant Activity}

The antioxidant potential is in an inverse relation with $\mathrm{IC}_{50}$ value that can be calculated from logarithmic regression of the $\%$ inhibition versus antioxidant activity. Lower the $\mathrm{IC}_{50}$ value indicates high antioxidant activity. All the calculations are based on the standard method given by Brand-Williams et al,. 1995. Absorbance was measured at $517 \mathrm{~nm}$. Absorbance of each solution was measured and recorded below. 
Table 3: Result of DPPH scavenging

\begin{tabular}{|c|c|}
\hline Concentration $(\mathbf{m g} / \mathbf{m L})$ & Percentage scavenged \\
\hline 1 & 47.26 \\
\hline 2 & 62.39 \\
\hline 4 & 79.83 \\
\hline 10 & 81.12 \\
\hline
\end{tabular}

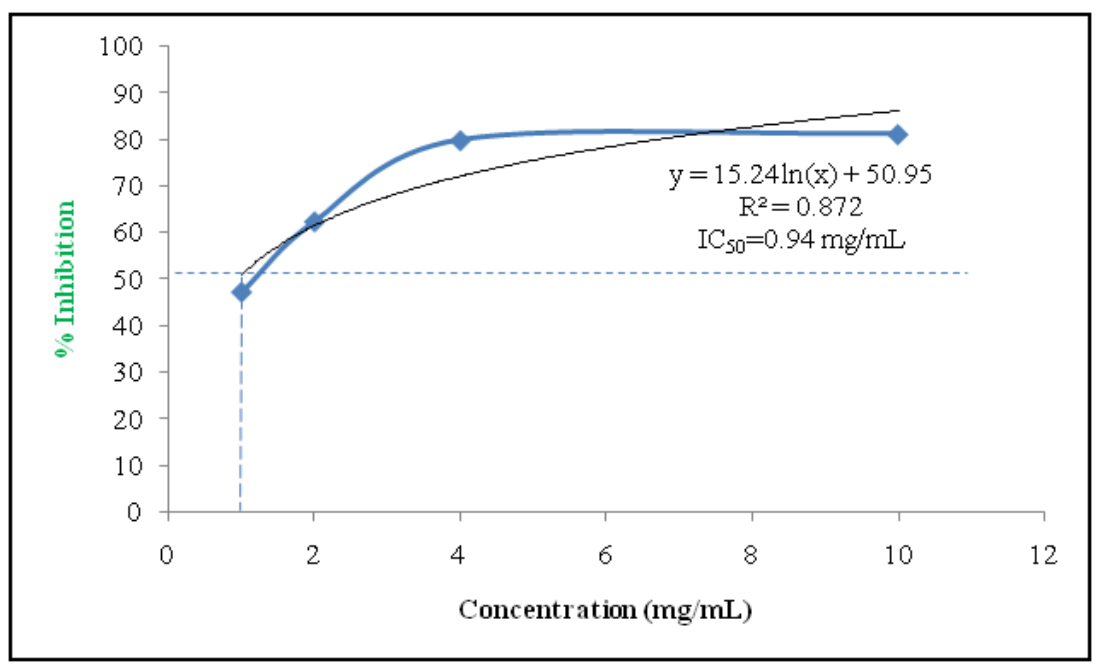

Fig 2: Graphical representation of DPPH assay of essential oil of T.ammi

The $\mathrm{IC}_{50} \pm \mathrm{SEM}$ (Standard Error Mean) of the oil was found to be $0.94 \mathrm{mg} / \mathrm{mL}$.

From this result, it is known that essential oil of $T$. ammi is very good for the drug development against oxidative action.

\section{Brine Shrimp lethality assay}

The nauplii were exposed to each of different concentrations of the essential oil and number of motile nauplii was calculated for the percentage of lethality of the brine shrimp nauplii after 24 hours. The presence of cytotoxic principles in the essential oil is indicated by the percentage of mortality of Brine Shrimp nauplii produced by the $T$. ammi with the increment of concentration. This study showed that $\mathrm{LC}_{50}$ value of essential oil of $T$. ammi was $26.20 \mu \mathrm{g} / \mathrm{mL}$.

\section{Conclusions}

GC-MS analysis of oil showed the presence of 10 different compounds. The most abundant were $\gamma$-terpinene (53.81\%) and thymol (29.40\%). Staphylococcus aureus, Enterobacter cloaceae and Bacillus subtilis were most susceptible to the essential oil, out of six bacterial species used, by showing ZOI $1.4 \mathrm{~cm}, 1.5 \mathrm{~cm}$ and $1.4 \mathrm{~cm}$ respectively. The $\mathrm{IC}_{50}$ value of the oil against DPPH was calculated as $0.94 \mathrm{mg} / \mathrm{mL}$ from the data obtained whereas $\mathrm{LC}_{50}$ value against brine shrimp was calculated as $26.20 \mu \mathrm{g} / \mathrm{mL}$.

\section{Acknowledgements}

We are thankful to Department of Chemistry, Amrit Science Campus, Lainchaur, Kathmandu, Nepal and Kathmandu Valley School and College, Chhauni, Kathmandu, Nepal for laboratory facilities. We express our gratitude to Department of Food Technology and Quality Control, Babarmahal, Kathmandu, Nepal for GC-MS analysis. Also, sincere thanks to Research Institution of Bioscience and Biotechnology (RIBB), Lalitpur, Nepal for bioactivities. We are also grateful to Dr. Bishnu P. Marasini, Department of Biotechnology, National College, Kathmandu for his help and support. 


\section{References}

Bairwa, R., Sodha, R. S., and Rajawat, B. S. 2012. Trachyspermum ammi. Pharmacognosy Reviews. 6(11): 56.

Brand-Williams, W., Cuvelier, M. E., and Berset, C. L. W. T. 1995. Use of a free radical method to evaluate antioxidant activity. LWT-Food Science and Technology. 28(1): 25-30.

Chahal, K. K., Dhaiwal, K., Kumar, A., Kataria, D., and Singla, N. 2017. Chemical composition of Trachyspermum ammi L. and its biological properties: A review. Journal of Pharmacognosy and Phytochemistry. 6(3): 131-140.

Chatterjee, S., Goswami, N., and Kothari, N. 2013. Evaluation of antioxidant activity of essential oil from Ajwain (Trachyspermum ammi) seeds. International Journal of Green Pharmacy (IJGP). 7(2): 140-144.

Chung, I. M., Khanh, T. D., Lee, O. K., and Ahmad, A. 2007. Chemical constituents from ajwain seeds (Trachyspermum ammi) and inhibitory activity of thymol, lupeol and fatty acids on barnyardgrass and radish seeds. Asian Journal of Chemistry. 19(2): 1524 .

Dhaiwal, K., Chahal, K. K., Kataria, D., and Kumar, A. 2017. Gas chromatography $\square$ mass spectrometry analysis and in vitro antioxidant potential of ajwain seed (Trachyspermumammi L.) essential oil and its extracts. Journal of Food Biochemistry. 41(3): e12364.

Gandomi, H., Abbaszadeh, S., JebelliJavan, A., and Sharifzadeh, A. 2014. Chemical constituents, antimicrobial and antioxidative effects of Trachyspermum ammi essential oil. Journal of Food Processing and Preservation. 38(4): 1690-1695.

Khajeh, M., Yamini, Y., Sefidkon, F., and Bahramifar, N. 2004. Comparison of essential oil composition of Carum copticum obtained by supercritical carbon dioxide extraction and hydrodistillation methods. Food Chemistry. 86(4): 587-591.

Medini, F., Fellah, H., Ksouri, R., and Abdelly, C. 2014. Total phenolic, flavonoid and tannin contents and antioxidant and antimicrobial activities of organic extracts of shoots of the plant Limonium delicatulum. Journal of Taibah University for Science. 8(3): 216-224.

Meyer, B. N., Ferrigni, N. R., Putnam, J. E., Jacobsen, L. B., Nichols, D. J., and McLaughlin, J. L. 1982. Brine shrimp: a convenient general bioassay for active plant constituents. Planta Medica. 45(05): 31-34.

Moazeni, M., Saharkhiz, M. J., and Hosseini, A. A. 2012. In vitro lethal effect of ajowan (Trachyspermum ammi L.) essential oil on hydatid cyst protoscoleces. Veterinary Parasitology. 187(1-2): 203-208.

Opoku, F., and Akoto, O. 2015. Antimicrobial and phytochemical properties of Alstonia boonei extracts. Organic Chemistry: Current Research. 4(1): 1.

Ranjan, B., Manmohan, S., Singh, S. R., and Singh, R. B. 2012. Medicinal uses of Trachyspermum ammi: a review. Pharmacognosy Reviews. 6(11): 56-60.

Shojaaddini, M., Moharramipour, S., and Sahaf, B. 2008. Fumigant toxicity of essential oil from Carum copticum against Indian meal moth, Plodiainterpunctella. Journal of Plant Protection Research. 48(4): 411-419.

Singh, A. \& Ahmad, A. (2017). Antioxidant Activity of Essential Oil Extracted by $\mathrm{SC}_{-} \mathrm{CO}_{2}$ from seeds of Trachyspermum ammi. Medicines. 4(3): 53.

Singh, G., Marimuthu, P., Murali, H. S., and Bawa, A. S. 2005. Antioxidative and antibacterial potentials of essential oils and extracts isolated from various spice materials. Journal of Food Safety. 25(2): 130-145.

Vazirzadeh, M., Zaboli, J., Mohsenzadeh, S., Teixeira da Silva, J. A., Karbalaei-Heidari, H. R., and Robati, R. 2013. Antibacterial activity of Ajowan (Trachyspermum copticum) seed extract. Medicinal and Aromatic Plant Science and Biotechnology. 7(1): $54-55$.

Zarshenas, M. M., Moein, M., Samani, S. M., and Petramfar, P. 2013. An overview on ajwain (Trachyspermum ammi) pharmacological effects; modern and traditional. Journal of Natural Remedies. 14(1): 98-105. 